\title{
Lobesia arzilae sp. n. and Willibaldiana culatrae sp. n. new species from Portugal (Lepidoptera: Tortricidae: Olethreutinae)
}

\section{P. Trematerra}

Department of Agriculture, Environment and Food Sciences, University of Molise, Campobasso, Italy

\begin{abstract}
Lobesia arzilae sp. n. and Willibaldiana culatrae sp. n. (Lepidoptera: Tortricidae: Olethreutinae) found in Portugal are described. The new species were collected respectively in Paúl de Arzila, a nature reserve located in central-west Portugal, close to the city of Coimbra and in Ilha da Culatra, which lies in the Parque Natural da Ria Formosa, in the region of Faro, situated in the extreme south of Portugal. L. arzilae differs from other species of the genus Lobesia by male genitalia; socius is lateral, developed extending upwards; sacculus has a group of long spines apically dentate and is armed with strong dorsal thorn. $W$. culatrae differs from other species of the genus Willibaldiana by genitalia: in male valva is simple, in female cingulum is long and developed. Images of the holotypes and the genitalia are provided.
\end{abstract}

\section{Introduction}

After Isotrias penedana Trematerra, 2013, Tortricidae of subfamily Chlidanotinae tribe Polyorthini, collected in Serra da Peneda, Portugal (Trematerra, 2013), two more new Portuguese tortricids assigned to genus Lobesia Guenée, 1845 and Willibaldiana Knud Larsen, 2013, are described: Lobesia arzilae sp. n. (Olethreutinae: Olethreutini) from Paúl de Arzila, (Coimbra, Beira Litoral), and Willibaldiana culatrae sp. n. (Olethreutinae: Eucosmini) from Algarve (Ilha da Culatra) (Brown, 2005; Razowski, 1989, 2003; Larsen, 2013).

Paúl de Arzila, a nature reserve in the lower Mondego Valley, is a freshwater marsh with an extensive reedbed, located in central-west Portugal, close to the city of Coimbra; Ilha da Culatra is a small island, forming part of the Parque Natural da Ria Formosa, in the region of Faro, situated in the extreme south of Portugal.

\section{Lobesia arzilae sp. $\mathrm{n}$.}

MATERIAL EXAMINED: 1 male, holotypus, labelled as follows: P7482, Portugal, Paúl de Arzila, Coimbra, Beira Litoral, 24.IX.2004, M.F.V. Corley. 1 male genitalia preparation (Corley 2161) Portugal, Torre, Taipal, Montemor-o-Velho, Beira Litoral, 7.IV.2004, P. Pires (this specimen was in poor condition and is probably lost, but the genitalia are very clearly the same as the Arzila specimen).

ADULT. Wingspan 9-12 mm (Figure 1). Antenna brownish. Head light brown, palpi brownish light brown, inner part whitish. Frons and vertex concolorous with palpus. Thorax light brown, tegula brown with light brown edge. Ground colour of forewing whitish, in distal part of wing slightly creamier or ochreous creamy. Strigulae brownish. Markings brown to blackish brown: basal blotch consisting of several stripes and spots; median fascia broad, rust-brown with blackish
Correspondence: Pasquale Trematerra, Dipartimento di Agricoltura, Ambiente e Alimenti, Università degli Studi del Molise, via de Sanctis, 86100 Campobasso, Italy.

E-mail: trema@unimol.it

Key words: Lobesia arzilae sp. n., Willibaldiana culatrae sp. n., Lepidoptera Tortricidae, Olethreutinae, new species, Portugal.

Acknowledgements: the author would like to express his thanks to Leif Aarvik (Norway), Joaquin Baixeras (Spain), Jozef Razowski (Poland), and Martin Corley (England) for comments and providing the study material.

Received for publication: 13 September 2013.

Revision received: 11 December 2013.

Accepted for publication: 29 January 2014.

CCopyright P. Trematerra, 2014

Licensee PAGEPress, Italy

Journal of Entomological and Acarological Research 2014; 46:1923 doi:10.4081/jear.2014.1923

This article is distributed under the terms of the Creative Commons Attribution Noncommercial License (by-nc 3.0) which permits any noncommercial use, distribution, and reproduction in any medium, provided the original author(s) and source are credited.

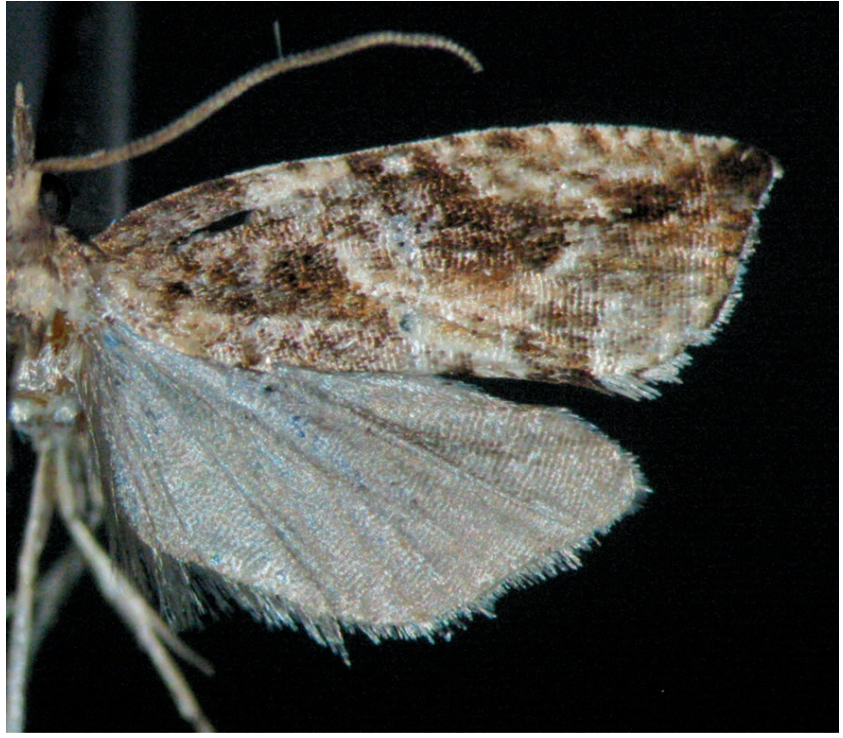

Figure 1. Lobesia arzilae sp. n., adult. 
brown places, interrupted postmedially; terminal area brownish ferruginous, darker at apex. Cilia pale cream suffused brown from apex of wing to middle of termen, concolorous with ground colour at tornus. Hindwing light brownish grey; cilia grey or whitish grey.

MALE GENITALIA (Figures 2-4). Top of tegumen rounded, uncus

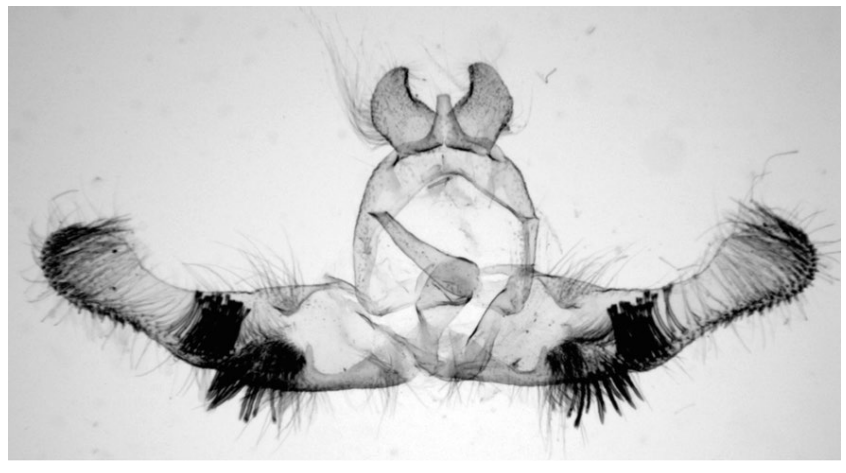

Figure 2. Lobesia arzilae sp. n., male genitalia.

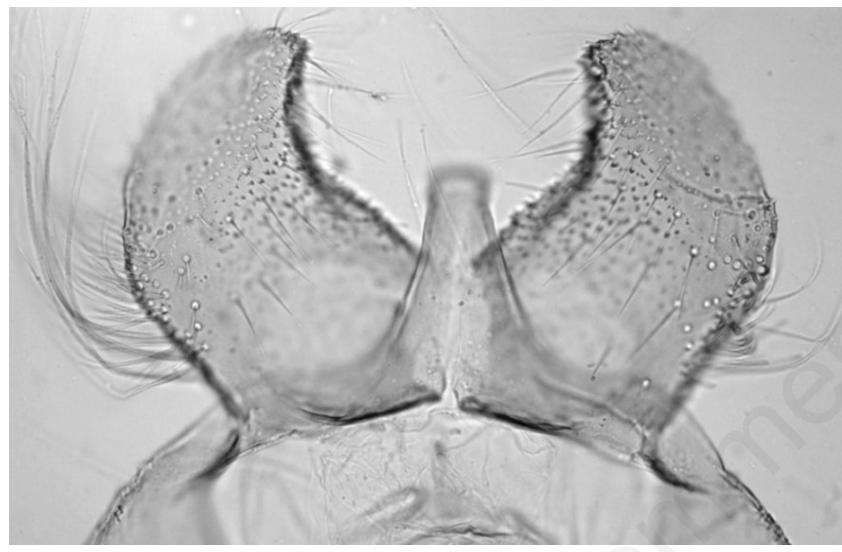

Figure 3. Lobesia arzilae sp. n., male genitalia. Uncus and socius.

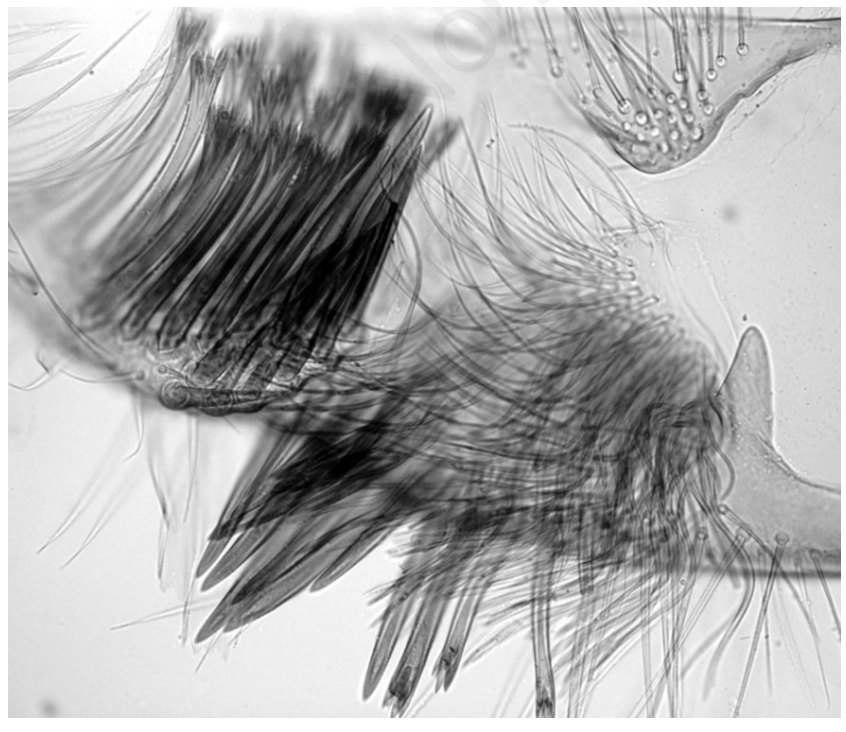

Figure 4. Lobesia arzilae sp. n., male genitalia. Sacculus with thorn and groups of bristles and spines. short; socius lateral, developed extending upward, provided with delicate bristles. Valva elongate; basal cavity wide; sacculus with anterior group of long and slender bristles, angular group of large spines mixed with few dentate spines, a group of long dentate spines along median half ventrally; sacculus distinctly convex near middle ventrally, armed with a strong dorsal thorn; cucullus rounded distinct also spiny; ventral incision small. Aedeagus moderately long.

FEMALE GENITALIA. Unknown.

DISTRIBUTION. Known only from two sites in the lower Mondego valley, west of Coimbra: Paúl de Arzila and Montemor-o-Velho, Coimbra, Beira Litoral, central-west Portugal.

HOST. Unknown.

BIOLOGY. The holotype male was trapped at light in late September, but the Montemor-o-Velho specimen was taken in April, so there must be two generations. The Arzila site is a track separating the marsh, dominated by Phragmites australis (Cav.) Trin. ex Steud., with some marginal Salix atrocinerea Brot. and Fraxinus angustifolia Vahl, from drier sloping ground with Crataegus monogyna Jacq., Rubus ulmifolius Schott and Quercus faginea Lam.

DIAGNOSIS. L. arzilae differs from other species of the genus Lobesia by male genitalia. Socius is lateral, developed extending upwards; sacculus has groups of long dentate spines along posterior half ventrally and is armed with a strong dorsal thorn.

The type specimen and slide of male genitalia of $L$. dearzilae are deposited in the Trematerra Collection, University of Molise, Campobasso, Italy.

ETYMOLOGY. The new species is named after Paúl de Arzila (Portugal), the area from which the holotype comes.

\section{WIlibaldiana culatrae sp. $\mathrm{n}$.}

MATERIAL EXAMINED. 1 male, holotypus, labelled as follows: P10329, Portugal, Ilha da Culatra, Algarve, 18.VIII.2008, P. Pires. + 1 male with same data. Paratypes, 2 males, 1 female Portugal, Ilha da Culatra, 3.VIII.2008, J. P. Cardoso in coll. M. Corley.

ADULT (Figure 5). Wingspan 9-12 mm. Antenna white-cream. Head white-creamy, palpi concolorous sprinkled with light brown. Frons and vertex concolorous with palpus. Thorax and tegula light cream. Abdomen yellowish-brown. Ground colour of forewing white delicately suffused brownish; lines between markings and costal dividings darker; speculum white with brownish inner suffusion and brownish spots.

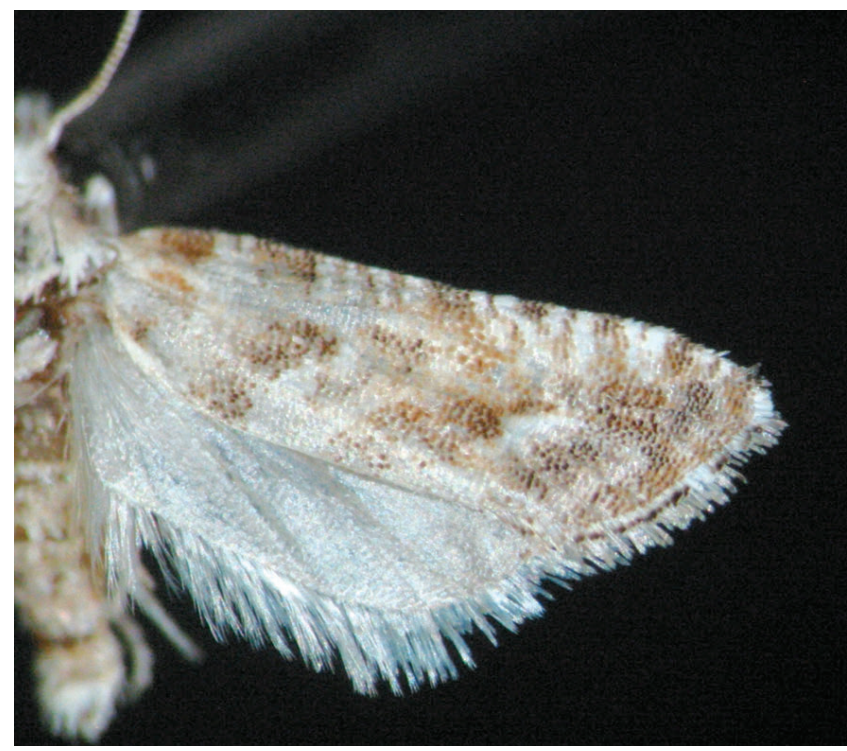

Figure 5. Willibaldiana culatrae sp. n., adult. 
Marking brownish with lighter suffusions or dots along edges: dorsopostbasal fascia fusing with the subcostal marking; submedian interfascia with light brown stripes; median fascia interrupted in the middle; subterminal fascia and subapical markings fused. Cilia light brown, brown at base. Hindwing pale cream with the apex brownish; cilia concolorous with wing.

MALE GENITALIA (Figures 6-9). Uncus minute; tegumen delicate; socius slender, hairy: tuba analis membranous. Valva elongate, sacculus

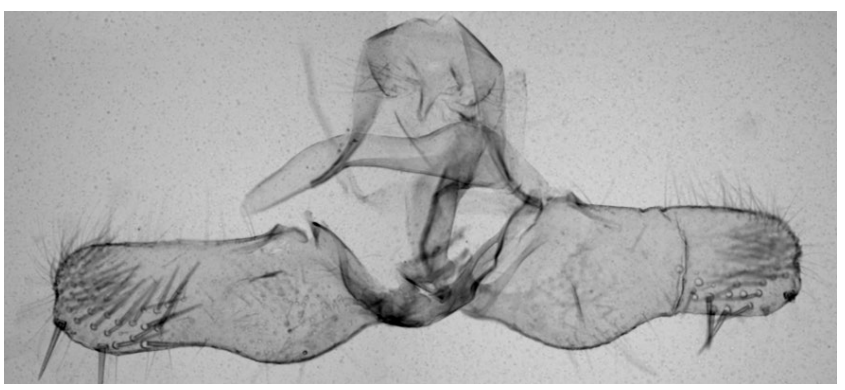

Figure 6. Willibaldiana culatrae sp. n., male genitalia.

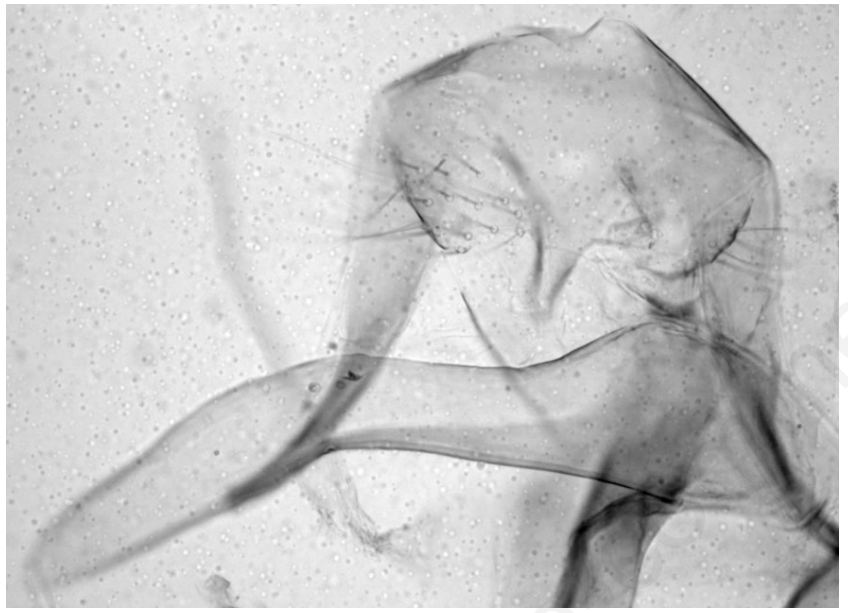

Figure 7. Willibaldiana culatrae sp. n., male genitalia. Tegumen and aedeagus.

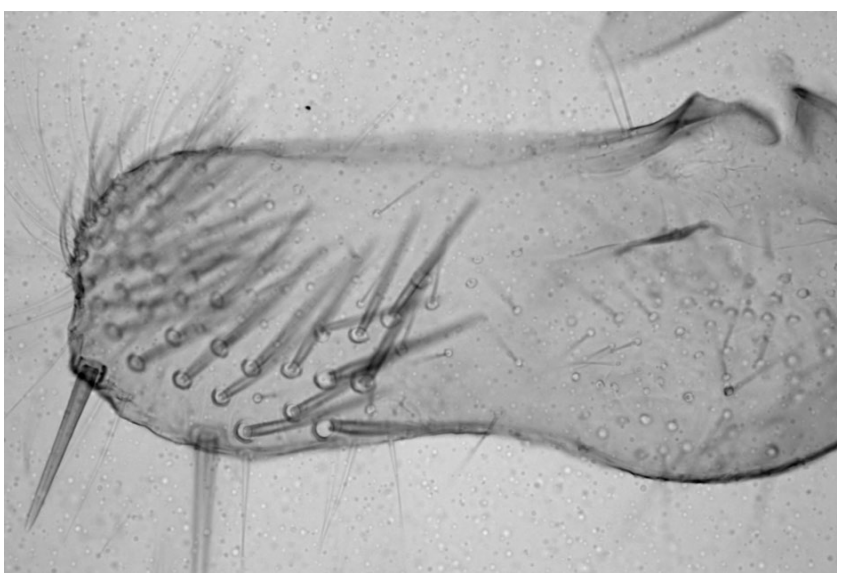

Figure 8. Willibaldiana culatrae sp. n., male genitalia. Valva. short and curved; ventral edge of sacculus less than half length of valva; pulvinus indistinct; neck of valva moderately broad; cucullus rounded, with slender spines. Aedeagus long and slender, open dorso-posteriorly.

FEMALE GENITALIA (Figures 10 and 11). Postostial part of sterigma provided with indistinct latero-posterior lobes, anteostial part large, expanding distally; sclerite of colliculum absent; cingulum long extending from base of bursa copulatrix to before end of ductus bursae; signa broad, rounded, unequally sized.

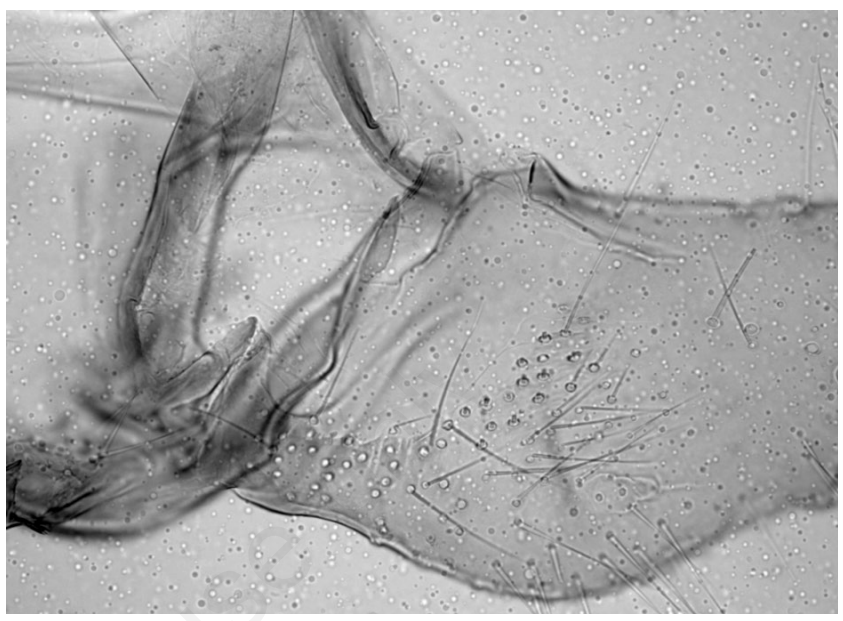

Figure 9. Willibaldiana culatrae sp. n., male genitalia. Basal cavity of valva and pulvinus.

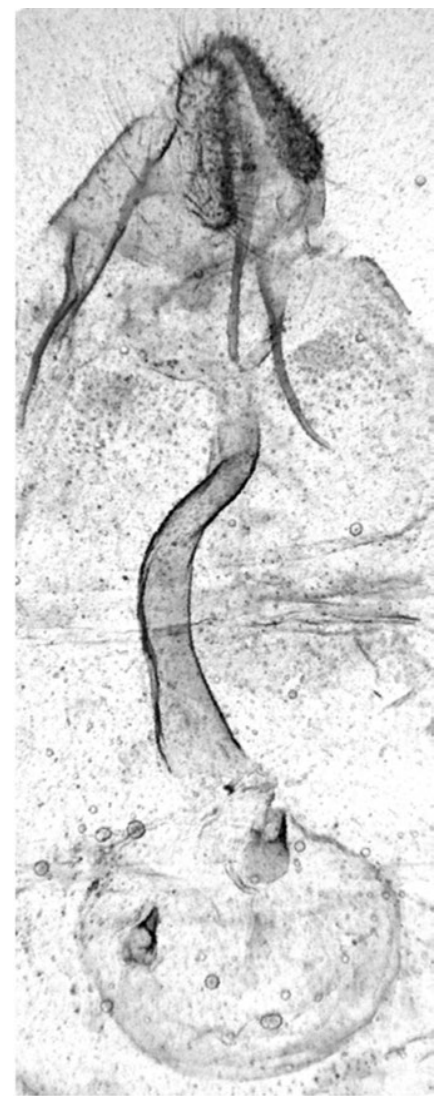

Figure 10. Willibaldiana culatrae sp. n., female genitalia. 
DISTRIBUTION. Known only from Algarve, Ilha da Culatra, southern Portugal.

HOST. Unknown.

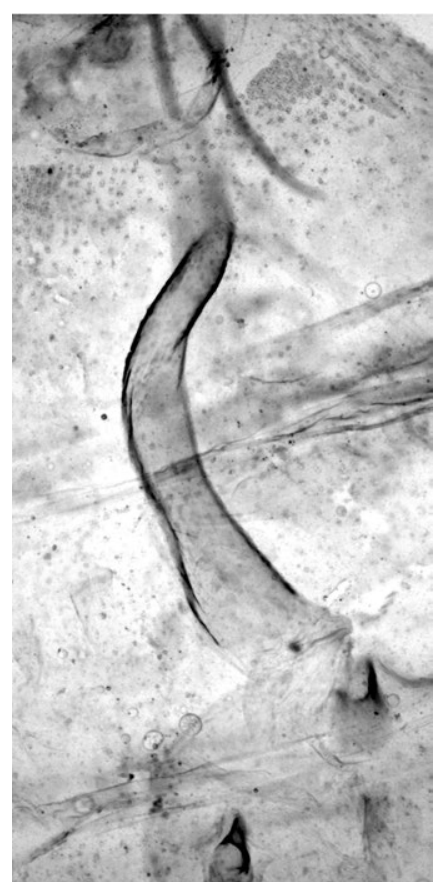

Figure 11. Willibaldiana culatrae sp. n., female genitalia. Antrum, cingulum and signa.
BIOLOGY. Adults were collected at light during August. Ilha da Culatra is low and windswept with sparse dune vegetation consisting of plants such as Lotus creticus L., Medicago marina L., Otanthus maritimus (L.) Hoffmanns \& Link, Armeria maritima (Mill.) Willd., Thymus carnosus Boiss., Helichrysum italicum (Roth) G. Don, Ammophila arenaria (L.) Link and Eryngium maritimum L The northern side of the island has salt marsh vegetation, but the collection site is in the sandy part.

DIAGNOSIS. W. culatrae differs from $W$. paasi Knud Larsen, 2013, and W. schmitzi Knud Larsen, 2013, by light wings and by male and female genitalia. In male valva is simple, in female cingulum is long and more developed.

The type specimens of $W$. culatrae are deposited in the Trematerra Collection, University of Molise, Campobasso, Italy, and three paratypes are deposited in the private collection of Martin Corley, England.

ETYMOLOGY. The new species is named after Ilha da Culatra (Portugal), the island from which the type series comes.

\section{References}

BROWN J., 2005 - World catalogue of insects. Vol. 5. Tortricidae (Lepidoptera). - Apollo Books, Stenstrup: 1-741.

LARSEN K., 2013 - A new genus and two new species of Tortricidae (Lepidoptera) from the Canary Islands. - Phegea 41: 50-54.

RAZOWSKI J., 1989 - The genera of Tortricidae (Lepidoptera). Part II: Palaearctic Olethreutinae. - Acta Zool. Cracov. 32: 107-328.

RAZOWSKI J., 2003 - Tortricidae of Europe. Vol. 2. Olethreutinae. Frantisek Slamka, Bratislava: 1-301.

TREMATERRA P., 2013 - Isotrias penedana sp. n. a new species of Lepidoptera (Tortricidae: Chlidanotinae: Polyorthini) from Portugal. - J. Entomol. Acarol. Res. 45: 93-95. 